Forschende

Komplementärmedizin und

Klassische Naturheilkunde

\section{Contents of Next Issues - Themenvorschau}

Forsch Komplementärmed Klass Naturheilkd 2005;12:184
Originalarbeiten

Methodology
Intrakranieller Druckanstieg nach zerebralen Blutflussgeschwindigkeitsänderungen durch Akupressur, Nadelakupunktur und Lasernadelakupunktur?

Litscher, G.; Wang, L.; Schwarz, G. (Graz); Schikora, D. (Paderborn)

The Effectiveness of Balneotherapy in Chronic Low Back Pain - a Randomised, Double-Blind Controlled, Follow-up Study

Balogh, Z.; Ördögh, J.; Gász, A.; Német, L. (Kehidakustány); Bender, T. (Budapest)

Reduction in the Number of Infective Trichinella spiralis Larvae in Mice by Use of Homeopathic Drugs

Sukul, N.C.; Ghosh, S.; Sinhababu, S.P. (West Bengal)

Patient-Practitioner-Remedy (PPR) Entanglement. Part 8: Laser-Like Action of the Homeopathic Therapeutic Encounter as Predicted by a Gyroscopic Metaphor for the Vital Force

Milgrom, L.R. (London)

Much Ado about Entanglement: A Novel Approach to Test Nonlocal Communication via Violation of Local Realism Schmid, G.B. (Winterthur) 